\title{
BMJ Open Cohort profile: Actionable Register of Geneva Outpatients and inpatients with SARS-CoV-2 (ARGOS)
}

Camille Genecand, ${ }^{1,2}$ Denis Mongin, ${ }^{1,3}$ Flora Koegler (D) , ${ }^{4}$ Dan Lebowitz, ${ }^{5}$ Simon Regard, ${ }^{1,6}$ Jean-Luc Falcone, ${ }^{7}$ Mayssam Nehme (D) , ${ }^{2}$ Olivia Braillard, ${ }^{2}$ Marwène Grira, ${ }^{2}$ Dominique Joubert, ${ }^{8}$ Pierre Chopard, ${ }^{8}$ Elisabeth Delaporte, ${ }^{1}$ Jérôme Stirnemann, ${ }^{4}$ Idris Guessous, ${ }^{2}$ Aglaé Tardin, ${ }^{1}$ Delphine S Courvoisier (D) ${ }^{1,8}$

To cite: Genecand C, Mongin D, Koegler F, et al. Cohort profile: Actionable Register of Geneva Outpatients and inpatients with SARSCoV-2 (ARGOS). BMJ Open 2021;11:e048946. doi:10.1136/ bmjopen-2021-048946

- Prepublication history for this paper is available online. To view these files, please visit the journal online (http://dx.doi. org/10.1136/bmjopen-2021048946).

Received 11 January 2021 Accepted 29 0ctober 2021
Check for updates

(C) Author(s) (or their employer(s)) 2021. Re-use permitted under CC BY-NC. No commercial re-use. See rights and permissions. Published by BMJ.

For numbered affiliations see end of article.

Correspondence to Dr Camille Genecand; camille.genecand@etat.ge.ch

\section{ABSTRACT}

Purpose The Actionable Register of Geneva Outpatients and inpatients with SARS-CoV-2 (ARGOS) is an ongoing prospective cohort created by the Geneva Directorate of Health. It consists of an operational database compiling all SARS-CoV-2 test results recorded in the Geneva area since late February 2020. This article aims at presenting this comprehensive cohort, in light of some of the varying public health measures in Geneva, Switzerland, since March 2020.

Participants As of 1 June 2021, the database included 360525 patients, among which 65475 had at least one positive test result for SARS-CoV-2. Among all positive patients, $37.6 \%$ were contacted only once, $10.6 \%$ had one follow-up call, $8.5 \%$ had two and $27.7 \%$ had three or more follow-up calls. Participation rate among positive patients is $94 \%$. Data collection is ongoing.

Findings to date ARGOS data illustrates the magnitude of COVID-19 pandemic in Geneva, Switzerland, and details a variety of population factors and outcomes. The content of the cohort includes demographic data, comorbidities and risk factors for poor clinical outcome, self-reported COVID-19 symptoms, environmental and socioeconomic factors, prospective and retrospective contact tracing data, travel quarantine data and deaths. The registry has already been used in several publications focusing on symptoms and long COVID-19, infection fatality rate and re-infection. Future plans The data of this large real-world registry provides a valuable resource for various types of research, such as clinical research, epidemiological research or policy assessment as it illustrates the impact of public health policies and overall disease burden of COVID-19.

\section{INTRODUCTION}

In December 2019, an increasing number of pneumonia cases caused by a novel coronavirus, SARS-CoV-2, was observed in Wuhan, China. On 11 March 2020, the WHO declared the COVID-19 outbreak a global pandemic. ${ }^{12}$ As of 1 June 2021, the virus spread to 207 countries, infected close to 171 million people and caused 3.68 million deaths. ${ }^{34}$ In Switzerland, the cumulative incidence of laboratory confirmed COVID-19 cases during the first
Strengths and limitations of this study

- Actionable Register of Geneva Outpatients and inpatients with SARS-CoV-2 (ARGOS) main strength consists of its large number of cases, representative of all diagnosed cases on a regional level, with the primary aim of assessing all patients.

- ARGOS involves every individual who performed a SARS-CoV-2 test (PCR or antigenic) and is not limited to hospitalised patients, thus providing a valuable resource to assess the overall disease burden of COVID-19 in a geographically defined population.

- To mitigate confounding effects and improve data analysis and interpretation, we present the data according to four policy periods.

- This cohort is multicentric as it includes all tests performed and recorded by Geneva's hospitals (both public and private), private practices and medical centres.

- Due to operational needs, symptoms and comorbidities are self-reported, which may lead to measurement error or misclassification.

wave was in the top five countries in Europe, with about 400 confirmed cases per 100000 population at the end of July $2020 .{ }^{45}$ In the Geneva area, the first patient with COVID-19 was diagnosed on 26 February $2020 .{ }^{6}$ Possibly due to the city's geographical proximity to Northern Italy, ${ }^{7}$ the epidemic curve showed a steep upward trend. The first wave of the epidemic peaked in Geneva on 2 April with 233 cases in 24 hours in an area with a population of 500 000. At that time, Geneva's cumulative incidence of confirmed cases was almost three times that of Switzerland, ${ }^{5}$ with more than 1000 cases per 100000 population, ${ }^{6}$ while the seroprevalence was estimated to be close to 10 times that of the confirmed cases as $9.7 \%$ of the population had antibodies 3 weeks after the height of the epidemic. ${ }^{89}$

A database was created in early March in order to contact new cases and keep track 
of their follow-up. The Actionable Register of Geneva Outpatients and inpatients with SARS-CoV-2 (ARGOS) includes all SARS-CoV-2 test results conducted in the Geneva area since late February 2020, as well as those from Geneva residents being tested in other Swiss cantons. After more than a year of pandemic and guided by operational needs, ARGOS has been enriched by various data, including contact tracing information. The primary aim of this article is to present this comprehensive cohort, its characteristics and the content of the data collected. The secondary aim is to interpret the data according to some of the public health measures implemented over time since the cohort profile was influenced by the varying policies enacted by the Swiss government and the Geneva State.

\section{COHORT DESCRIPTION ARGOS database}

ARGOS is an ongoing prospective cohort created by the Geneva Directorate of Health (GDH) and consists of an operational database compiling all SARS-CoV-2 test results conducted in the Geneva canton. Data are collected and managed using the REDCap electronic data capture tools ${ }^{10}{ }^{11}$ allowing the GDH to contact positive cases in order to promote public health measures and coordinate medical follow-up. It is set up as a collaborative tool between different institutions and medical entities, including the GDH, Geneva University Hospitals (HUG), and Geneva's main private medical centres. The latter have restricted access to data regarding their own patients only. The GDH and HUG are the only users to implement follow-up data in the electronic register. The data is hosted on HUG's secure servers. The register is administered by a committee of coprincipal investigators belonging to the GDH and HUG, with the agreement of the cantonal ethic committee. Participants in the database had the opportunity to refuse to participate in the registry, and those who did are excluded from the analyses presented here and any data sharing. The participation rate for positive patients is $93.9 \%$ (calculated as the ratio between the number of patients who gave their consent for the reuse of their data and the total number of patients). As recommended by the WHO, deidentified ARGOS data are made available on reasonable request, including a research protocol, using the online form (https://edc.hcuge.ch/surveys/?s=TLT9EHE93C).

\section{Data collection}

All Geneva laboratories performing SARS-CoV-2 testing are required to send the results to the GDH. Swabs are collected from the upper respiratory tract in medical centers, private practice or during home visits by trained healthcare professionals. ${ }^{12}$ Between 24 January 2020 and 1 June 2021, 655527 tests for SARS-CoV-2 recorded in the ARGOS database, 584573 were performed by realtime reverse transcriptase-PCR assays and 70954 by rapid antigen tests. The majority were performed in the Geneva area and a small number consisted of tests conducted on Geneva residents in other Swiss Cantons, and declared to the GDH by the Federal Office of Public Health (FOPH). Importantly, patients reporting COVID-19 symptoms between 13 March and 29 March 2020, did not get tested due to shortage of testing materials, unless they were healthcare workers, considered at-risk or hospitalised. However, symptomatic patients who visited the HUG COVID-19 testing centre without fulfilling testing criteria were entered in the database as 'suspected cases'. Some of these patients later received a test as policy evolved on 30 March 2020. For each positive or suspect case, a series of surveys is filled using REDCap platform. Depending on the needs, follow-up calls are performed either by a professional nurse, a medical student or a contact tracer with supervision from a medical doctor. Findings are documented in the database. Six hundred and sixty-nine patients from the cohort were also called back at 6 weeks and 7 months to monitor the persistence of symptoms, of which 510 and 410 answered, respectively. All SARSCoV-2 positive patients in Geneva who require hospitalisation at HUG received follow-up calls by the HUG team at the time of discharge from the hospital. COVID-19 positive patients identified as nursing home residents or who are hospitalised at the time of diagnosis are not systematically called since they already receive medical attention and isolation measures are enforced by the medical staff. During the second wave, which started in late September 2020, the incidence of SARS-CoV-2 positive patients became so high that the GDH team could not contact everyone in time. A semi-automatic process was put in place. Positive patients and their declared contacts received an invitation to an online survey where they filled basic information. Only then and when the workload allowed it, they received a phone call from the GDH team to complete the data already provided. At the peak of the second wave, not all SARS-CoV-2 positive patients could be contacted. Follow-up calls as well as calls to close contacts were also temporarily abandoned. Finally, the Geneva Cantonal Population Office are required to declare COVID-19 related deaths, which are also recorded in ARGOS. Patients or the public were not involved in research.

\section{What is being measured?}

An overview of collected data is provided in table 1 . The surveys were created by the GDH and HUG medical task forces. Within the first 48 hours of testing, patients with a positive test result for COVID-19 receive a call by a professional nurse or a trained contact tracer with support from a medical doctor if needed. During this call, demographic data are collected, ${ }^{13}$ as well as symptoms,${ }^{14-17}$ clinical and environmental risk factors, and clinical red flags. A special attention is paid to psychosocial and cultural factors, and resources are provided when needed. The clinical evaluation is used to identify patients who need immediate emergency care, or to address them for follow-up care by their general practitioner, by one of Geneva's 
Table 1 Actionable Register of Geneva Outpatients and inpatients with SARS-CoV-2 (ARGOS) collected data

\begin{tabular}{|c|c|}
\hline Test result & $\begin{array}{l}\text { Positive } \\
\text { Negative } \\
\text { COVID-19 suspected, no test performed } \\
\text { COVID-19 suspected, negative test result }\end{array}$ \\
\hline Test type & $\begin{array}{l}\text { RT-PCR } \\
\text { Rapid antigen test }\end{array}$ \\
\hline $\begin{array}{l}\text { Reason for } \\
\text { testing }\end{array}$ & $\begin{array}{l}\text { Acute symptoms consistent with COVID-19 } \\
\text { Screening, no symptoms } \\
\text { Screening in the workplace (no symptoms) } \\
\text { Screening based on Swisscovid notification (no } \\
\text { symptoms) }\end{array}$ \\
\hline Demographics & $\begin{array}{l}\text { Date of birth } \\
\text { Gender } \\
\text { Basic professional information } \\
\text { Personal and professional addresses } \\
\text { School information } \\
\text { - School address } \\
\text { - Name of class and professor }\end{array}$ \\
\hline $\begin{array}{l}\text { Medical risk } \\
\text { factors for } \\
\text { COVID-19 } \\
\text { negative outcome }\end{array}$ & $\begin{array}{l}\text { Cardiovascular disease } \\
\text { Hypertension } \\
\text { Obesity (based of calculated BMI) } \\
\text { Chronic respiratory disease } \\
\text { Chronic kidney disease } \\
\text { Cancer } \\
\text { Immunosuppression } \\
\text { Diabetes } \\
\text { Pregnancy } \\
\text { Smoking habits }\end{array}$ \\
\hline
\end{tabular}

\begin{tabular}{|c|c|}
\hline Vaccination & $\begin{array}{l}\text { Number of doses } \\
\text { Dates of doses }\end{array}$ \\
\hline $\begin{array}{l}\text { Environmental } \\
\text { risk factors }\end{array}$ & $\begin{array}{l}\text { Homelessness } \\
\text { Nursing home resident } \\
\text { Asylum seeker or other migrant living in a } \\
\text { collective housing } \\
\text { Living in another type of collective housing } \\
\text { Economic insecurity }\end{array}$ \\
\hline $\begin{array}{l}\text { Possible context } \\
\text { of infection }\end{array}$ & $\begin{array}{l}\text { In the family or living in the same household } \\
\text { In the workplace } \\
\text { At school } \\
\text { As a healthcare professional } \\
\text { During a public event } \\
\text { At a private party } \\
\text { In a night club } \\
\text { In a bar/restaurant } \\
\text { During a spontaneous gathering (including } \\
\text { between friends) } \\
\text { No idea }\end{array}$ \\
\hline Symptoms & $\begin{array}{l}\text { Cough } \\
\text { Presence of sputum } \\
\text { Dyspnoea } \\
\text { Fever }\left(>38^{\circ} \mathrm{C}\right) \\
\text { Chills } \\
\text { Headache } \\
\text { Fatigue } \\
\text { Arthralgia and/or myalgia } \\
\text { Sore throat } \\
\text { Rhinorrhoea, nasal congestion } \\
\text { Anosmia or ageusia } \\
\text { Gastrointestinal symptoms } \\
\text { Skin rash } \\
\text { None }\end{array}$ \\
\hline $\begin{array}{l}\text { Factors likely } \\
\text { to adversely } \\
\text { influence the } \\
\text { course of disease }\end{array}$ & $\begin{array}{l}\text { High anxiety level } \\
\text { Feeling of isolation } \\
\text { Difficulties in daily management }\end{array}$ \\
\hline
\end{tabular}

Continued

\begin{tabular}{|c|c|}
\hline Red flags & $\begin{array}{l}\text { New-onset or worsening dyspnoea } \\
\text { Fever for more than } 5 \text { days, or worsening fever } \\
\text { non responding to treatment } \\
\text { Deterioration of the general status } \\
\text { Worsening cough } \\
\text { Haemoptysis } \\
\text { Confusion } \\
\text { Gastrointestinal symptoms with dehydration } \\
\text { Moderate to severe chest pain }\end{array}$ \\
\hline $\begin{array}{l}\text { Positive patients' } \\
\text { self-reported } \\
\text { compliance to } \\
\text { recommended } \\
\text { isolation } \\
\text { measures }\end{array}$ & $\begin{array}{l}\text { Full compliance } \\
\text { Partial compliance } \\
\text { Insufficient compliance }\end{array}$ \\
\hline Timeline & $\begin{array}{l}\text { Date of symptom onset } \\
\text { Date of testing }\end{array}$ \\
\hline Death & $\begin{array}{l}\text { Site (at home, nursing home, hospital) } \\
\text { Date }\end{array}$ \\
\hline Contact tracing & $\begin{array}{l}\text { Number of close contacts per index case } \\
\text { Type of contact between index case and close } \\
\text { contact: } \\
\text { Living in the same household } \\
\text { Intimate contact } \\
\text { Professional } \\
\text { Healthcare environment } \\
\text { Social interaction } \\
\text { Recreational } \\
\text { Schooling } \\
\text { Date of last contact between index case and } \\
\text { close contact }\end{array}$ \\
\hline $\begin{array}{l}\text { Close contact } \\
\text { information }\end{array}$ & $\begin{array}{l}\text { Demographics } \\
\text { - } \text { - Gende of birth } \\
\text { - Personal and professional addresses } \\
\text { Vaccination information (number of doses, dates) } \\
\text { Environmental risk factors } \\
\text { - Homelessness } \\
\text { - Nursing home resident } \\
\text { - Asylum seeker or other migrant living in a } \\
\text { - collective housing } \\
\text { - Economing in ansecurer type of collective housing } \\
\text { - Healthcare professional } \\
\text { Presence of symptoms at first call and follow-up } \\
\text { calls } \\
\text { Compliance to quarantine measures at first call } \\
\text { and follow-up call } \\
\text { Quarantine period (dates of onset and end) } \\
\text { Tested positive during quarantine }\end{array}$ \\
\hline $\begin{array}{l}\text { Quarantine after } \\
\text { travelling in a red } \\
\text { list country }\end{array}$ & $\begin{array}{l}\text { Number of people in quarantine } \\
\text { Demographics } \\
\text { - } \text { - Gate of birth } \\
\text { - Pender } \\
\text { Red list country } \\
\text { - Name } \\
\text { - Date of departure } \\
\text { Vaccination (number of doses, dates) } \\
\text { Quarantine period (dates of onset and end) } \\
\text { Presence of symptoms at first call and follow-up } \\
\text { calls } \\
\text { Compliance to quarantine measures at first call } \\
\text { and follow-up call } \\
\text { Tested positive during quarantine }\end{array}$ \\
\hline
\end{tabular}

medical centres, or by the GDH-HUG team via telemedicine, which is recorded in the database as well. Patients' declared symptoms are recorded in subsequent surveys. 
Patients' self-reported compliance to isolation measures are also recorded. As of 27 April 2020, close contacts of index cases are individually contacted and basic information is recorded. Demographics, the type of contact they had with the index case, vaccine information, the presence of COVID-19 symptoms and their compliance to quarantine measures are also recorded at first call and during follow-up calls. Since 6 July 2020, the FOPH has established an evolving red list of countries where incidence rate is considered high or with variant of concern. Travellers who stayed in one of these countries have to quarantine for 10 days at their arrival in Switzerland. People staying in Geneva must self-declare on arrival and fill an online survey containing basic information which data is also part of ARGOS. Depending on the work load, travellers are called by contact tracers during their quarantine period. Self-reported compliance to quarantine measures and the presence of symptoms are recorded during these calls.

\section{FINDINGS TO DATE}

On 1 June 2021, of all 360525 patients recorded in the ARGOS database, 65475 had at least one positive test result, 294723 had one or more negative test results and no positive one, and 327 were suspected COVID-19 cases without a positive test to confirm the disease. During the same period, 655527 tests were performed, among which $89.2 \%$ were PCR. The positivity, that is, the ratio between the positive tests and the total amount of tests, was of $10.7 \%$. Among the positive patients, 4687 persons did not allow their data to be used for research and were excluded from analyses. The remaining number of positive cases available for analysis is 60788 . Of these patients, $37.6 \%$ have only a first telephone contact, $10.6 \%$ and $8.5 \%$ have one and two follow-up calls, respectively, and $27.7 \%$ of participants have three or more follow-up calls. $15.7 \%$ of the patients were not contacted, mainly during the periods of active pandemic activity when the GDH team was overworked (see table 2). The cohort shows a slight female predominance, with women representing $50.2 \%-55.9 \%$ of all patients depending on the defined period (table 2). More than $60 \%$ of all recorded patients have no risk factor for a poor clinical outcome. ${ }^{18}$ The context of infection recorded for COVID-19 positive patients since June 2020 indicates that infection mostly occurs at home, at work or via the educational system. Around $23.2 \%$ of the patients reported having no idea of their contamination context. Information about 114 690 close contacts of positive patients has been registered, and 639153 days of quarantine have been notified. Nine thousand five hundred and fifty-one close contacts of a positive COVID-19 case had a positive test result during their quarantine. Given that the standard duration of quarantine is 10 days, we can estimate that around $15 \%$ of the persons in quarantine after being in contact with a positive COVID-19 case received a positive test result during their quarantine (see table 2).
273189 days of quarantine concerning 27920 persons were ordered for persons coming back from a country at risk. As of 1 June 2021, these countries were in order of importance Spain (19.4\%), France (14.8\%), Kosovo $(7.6 \%)$, USA $(7.0 \%)$, UK (7.0\%), Portugal $(6.2 \%)$ and Brazil $(4.2 \%)$. Ninety-six persons received a positive test result during their travel quarantine, among which 26 came back from Kosovo, 11 from France and 10 from Spain, the total of these infections occurring in $0.35 \%$ of the quarantines.

To mitigate confounding effects and improve data analysis and interpretation, we present the data according to four periods (see figure 1).

\section{February to 27 April 2020 (first phase)}

The first phase starts on 26 February 2020, when the first case was tested positive for SARS-CoV-2 in the Geneva area. The Swiss authorities implemented lockdown measures which remained moderate in comparison with many other countries. ${ }^{19}$ This first phase ends on 27 April 2020, when some of the measures started to be lifted following the decreasing incidence of new cases and hospitalisations. During this first wave, contact tracing was not implemented. Between 13 March and 29 March 2020, symptomatic individuals did not get tested due to shortage of testing materials, unless they were healthcare workers, considered at-risk or hospitalised. The percentage of healthcare professionals among positive cases was significantly higher during this phase $(15.6 \%)$ and the percentage of patients declaring no risk factors was smaller $(32.4 \%)$ when compared with the other phases. The positivity rate (ie, the ratio between positive tests results and the total amount of test performed) was of $23 \%$.

\section{April to 24 September 2020 (second phase)}

Between May and the end of September 2020, incidence of SARS-CoV-2 positive cases remained low. Nearly all restrictions were lifted at the end of June. Nightclubs were closed again at the end of July after a surge of incidence mostly among Geneva youth, as can be seen by the relative higher incidence of the 20-39 years age category compared with the others during this period (figure 2). $14.1 \%$ of the positive tests during this period were stemming from screening campaigns and more than $70 \%$ of cases reported no risk factor. The positivity rate was only $4.6 \%$ during this period.

\section{September 2020 to 28 February 2021 (third phase)}

A second wave of SARS-CoV-2 positive cases hit Geneva in late September, 2020, at the same time as in the neighbouring countries. New restrictions were imposed midOctober but no real lockdown was enacted. The peak lasted about 8 weeks. Due to political and economic pressure, some restrictions measures were lifted long before incidence reached low level. The number of SARS-CoV-2 positive cases in Geneva area remained significant during several months. During February 2021, the B.1.1.7 variant 
Table 2 ARGOS baseline characteristics of positive patients, Geneva, 26 February 2020-1 June 2021. Periods are presented by grouping together the first wave of cases, the period between the first and second wave, the second wave and the following period of sustained epidemic activity, and finally the more recent period following the start of the vaccination campaign

\section{Overall \\ From 25 February 2020 From 27 April 2020 to to 27 April 2020 \\ From 24 September 2020 From 14 February 2021 \\ to 14 February 2021 \\ to 2 June 2021}

Number of positive patients

\begin{tabular}{|c|c|c|c|c|c|}
\hline $\mathrm{n}$ & 60788 & 5782 & 3274 & 40882 & 10824 \\
\hline Living in Geneva & $53344(88.2)$ & $4793(84.4)$ & $2827(86.5)$ & $35936(88.3)$ & $9775(90.4)$ \\
\hline \multicolumn{6}{|c|}{ Number of follow-ups per patient recorded in ARGOS } \\
\hline Not called & $9514(15.7)$ & $1135(19.6)$ & $108(3.3)$ & $8128(19.9)$ & $131(1.2)$ \\
\hline First contact only & $22847(37.6)$ & $3402(58.8)$ & $578(17.7)$ & 17541 (42.9) & $1316(12.2)$ \\
\hline 1 follow-up call & $6427(10.6)$ & $346(6.0)$ & $735(22.4)$ & $4387(10.7)$ & $959(8.9)$ \\
\hline 2 follow-up calls & $5178(8.5)$ & $152(2.6)$ & $683(20.9)$ & $2362(5.8)$ & $1977(18.3)$ \\
\hline $\begin{array}{l}3 \text { or more follow-up } \\
\text { calls }\end{array}$ & $16822(27.7)$ & 747 (12.9) & $1170(35.7)$ & $8464(20.7)$ & $6441(59.5)$ \\
\hline \multicolumn{6}{|l|}{ Age } \\
\hline $0-19$ & $6997(11.5)$ & $175(3.0)$ & $364(11.1)$ & $4052(9.9)$ & $2406(22.2)$ \\
\hline 20-39 & $21080(34.7)$ & $1690(29.2)$ & $1558(47.7)$ & $14356(35.1)$ & $3473(32.1)$ \\
\hline $40-64$ & 23879 (39.3) & $2567(44.4)$ & $1101(33.7)$ & 16007 (39.2) & $4202(38.8)$ \\
\hline $65-80$ & $5046(8.3)$ & $676(11.7)$ & $138(4.2)$ & $3693(9.0)$ & $539(5.0)$ \\
\hline$>80$ & $3750(6.2)$ & $674(11.7)$ & $108(3.3)$ & $2769(6.8)$ & $199(1.8)$ \\
\hline \multicolumn{6}{|l|}{ Gender } \\
\hline Male & $28314(46.6)$ & $2549(44.1)$ & $1628(49.8)$ & $18890(46.2)$ & $5238(48.4)$ \\
\hline Female & $32433(53.4)$ & $3233(55.9)$ & $1643(50.2)$ & 21972 (53.8) & $5574(51.5)$ \\
\hline Non binary & $22(0.0)$ & $0(0.0)$ & $1(0.0)$ & $8(0.0)$ & $12(0.1)$ \\
\hline \multicolumn{6}{|c|}{ Comorbidities and risk factors } \\
\hline $\begin{array}{l}\text { Cardiovascular } \\
\text { disease }\end{array}$ & $1835(3.0)$ & $396(6.8)$ & $95(2.9)$ & $1103(2.7)$ & $241(2.2)$ \\
\hline Hypertension & $4469(7.4)$ & $600(10.4)$ & $196(6.0)$ & $2968(7.3)$ & $705(6.5)$ \\
\hline Diabetes & $1975(3.2)$ & $273(4.7)$ & $95(2.9)$ & $1295(3.2)$ & $312(2.9)$ \\
\hline $\begin{array}{l}\text { Chronic respiratory } \\
\text { illness }\end{array}$ & $2170(3.6)$ & $512(8.9)$ & $83(2.5)$ & $1269(3.1)$ & $306(2.8)$ \\
\hline kidney & $229(0.4)$ & N/A & $\mathrm{N} / \mathrm{A}$ & $186(0.5)$ & $43(0.4)$ \\
\hline Cancer & $545(0.9)$ & $73(1.3)$ & $28(0.9)$ & $349(0.9)$ & $95(0.9)$ \\
\hline Immunosupression & $600(1.0)$ & $192(3.3)$ & $30(0.9)$ & $301(0.7)$ & $77(0.7)$ \\
\hline Obesity & $1081(1.8)$ & $\mathrm{N} / \mathrm{A}$ & $\mathrm{N} / \mathrm{A}$ & 778 (1.9) & $303(2.8)$ \\
\hline Age 65 and older & $8796(14.5)$ & $1350(23.3)$ & $246(7.5)$ & $6462(15.8)$ & $738(6.8)$ \\
\hline No risk factor & 36905 (60.8) & $1868(32.4)$ & $2523(77.1)$ & $24093(59.0)$ & $8419(77.8)$ \\
\hline Missing information & $8698(14.3)$ & $1854(32.1)$ & $209(6.4)$ & $6221(15.2)$ & $411(3.8)$ \\
\hline \multicolumn{6}{|l|}{ Other potential risks } \\
\hline Chronic disease & $787(1.3)$ & $56(1.0)$ & $28(0.9)$ & $550(1.3)$ & $152(1.4)$ \\
\hline Smoking & $4659(7.7)$ & $\mathrm{N} / \mathrm{A}$ & $\mathrm{N} / \mathrm{A}$ & $3345(8.2)$ & $1313(12.1)$ \\
\hline Pregnancy & $533(0.9)$ & $41(0.7)$ & $24(0.7)$ & $352(0.9)$ & $116(1.1)$ \\
\hline Other risk & $4284(7.0)$ & $107(1.9)$ & $364(11.1)$ & $2741(6.7)$ & $1072(9.9)$ \\
\hline \multicolumn{6}{|l|}{ Self-reported symptoms } \\
\hline Missing information & $12735(21.0)$ & $2632(45.5)$ & $264(8.1)$ & 9217 (23.3) & $604(5.0)$ \\
\hline $\begin{array}{l}\text { No symptoms ever } \\
\text { declared }\end{array}$ & $3893(6.4)$ & $254(4.4)$ & $416(12.7)$ & $1807(4.6)$ & $1413(11.6)$ \\
\hline $\begin{array}{l}\text { At least one } \\
\text { symptom }\end{array}$ & $44159(72.6)$ & $2896(50.1)$ & 2594 (79.2) & $28516(72.1)$ & $10148(83.4)$ \\
\hline \multicolumn{6}{|c|}{ Possible context of infection } \\
\hline Family & $17266(28.4)$ & $\mathrm{N} / \mathrm{A}$ & $511(15.6)$ & $11861(29.0)$ & $4889(45.2)$ \\
\hline Work & $8535(14.0)$ & $\mathrm{N} / \mathrm{A}$ & $304(9.3)$ & $6588(16.1)$ & $1639(15.1)$ \\
\hline
\end{tabular}

Continued
10824

$131(1.2)$

959 (8.9)

977 (18.3)

6441 (59.5)

2406 (22.2)

$539(5.0)$

$5238(48.4)$

$5574(51.5)$

$312(2.9)$

$43(0.4)$

$95(0.9)$

$77(0.7)$

$303(2.8)$ 
Table 2 Continued

\begin{tabular}{|c|c|c|c|c|c|}
\hline & Overall & $\begin{array}{l}\text { From } 25 \text { February } 2020 \\
\text { to } 27 \text { April } 2020\end{array}$ & $\begin{array}{l}\text { From } 27 \text { April } 2020 \text { to } \\
24 \text { September } 2020\end{array}$ & $\begin{array}{l}\text { From } 24 \text { September } 2020 \\
\text { to } 14 \text { February } 2021\end{array}$ & $\begin{array}{l}\text { From } 14 \text { February } 2021 \\
\text { to } 2 \text { June } 2021\end{array}$ \\
\hline School & $3302(5.4)$ & $\mathrm{N} / \mathrm{A}$ & $0(0.0)$ & $2200(5.4)$ & $1101(10.2)$ \\
\hline Healthcare worker & $894(1.5)$ & N/A & $17(0.5)$ & $808(2.0)$ & $67(0.6)$ \\
\hline Public event & $204(0.3)$ & $\mathrm{N} / \mathrm{A}$ & $22(0.7)$ & $138(0.3)$ & $44(0.4)$ \\
\hline Private_party & $1372(2.3)$ & N/A & $184(5.6)$ & $933(2.3)$ & $255(2.4)$ \\
\hline Club & $70(0.1)$ & $\mathrm{N} / \mathrm{A}$ & $24(0.7)$ & $41(0.1)$ & $5(0.0)$ \\
\hline $\begin{array}{l}\text { Spontaneous } \\
\text { gathering }\end{array}$ & $2527(4.2)$ & $\mathrm{N} / \mathrm{A}$ & $81(2.5)$ & $1718(4.2)$ & $728(6.7)$ \\
\hline No idea & $14090(23.2)$ & $\mathrm{N} / \mathrm{A}$ & $410(12.5)$ & $10451(25.6)$ & $3222(29.8)$ \\
\hline Other & $4921(8.1)$ & $\mathrm{N} / \mathrm{A}$ & $488(14.9)$ & $3574(8.7)$ & $858(7.9)$ \\
\hline Missing information & $16520(27.2)$ & $5775(100)$ & $1356(41.4)$ & $8885(21.7)$ & $486(4.5)$ \\
\hline \multicolumn{6}{|l|}{ Environmental risk factor } \\
\hline Homelessness & $135(0.2)$ & $15(0.3)$ & $6(0.2)$ & $102(0.2)$ & $12(0.1)$ \\
\hline $\begin{array}{l}\text { Nursing home } \\
\text { resident }\end{array}$ & $1895(3.1)$ & $377(6.5)$ & $63(1.9)$ & $1403(3.4)$ & $49(0.5)$ \\
\hline $\begin{array}{l}\text { Asylum seeker or } \\
\text { other migrant living } \\
\text { in a collective home }\end{array}$ & $267(0.4)$ & $25(0.4)$ & $2(0.1)$ & $172(0.4)$ & $68(0.6)$ \\
\hline $\begin{array}{l}\text { Collective home } \\
\text { resident (other than } \\
\text { migrant) }\end{array}$ & $627(1.0)$ & $34(0.6)$ & $31(0.9)$ & $431(1.1)$ & $131(1.2)$ \\
\hline \multicolumn{6}{|l|}{ Reason for testing } \\
\hline Positivity rate & 10.7 & 23.0 & 4.6 & 15.9 & 5.2 \\
\hline \multicolumn{6}{|l|}{ Deaths } \\
\hline Deaths number & 747 & 280 & 20 & 421 & 22 \\
\hline Age & $\begin{array}{l}87.1(80.2 \\
91.5)\end{array}$ & $86.3(79.4,91.3)$ & $89.2(85.8,93.3)$ & $87.7(81.4,91.8)$ & $83.6(70.5,90.3)$ \\
\hline Gender & $354(47.4)$ & $130(46.4)$ & $10(50.0)$ & $200(47.7)$ & $11(45.8)$ \\
\hline \multicolumn{6}{|l|}{ Contact tracing } \\
\hline $\begin{array}{l}\text { Number total of } \\
\text { contact }\end{array}$ & 114690 & 118 & 12420 & 77990 & 24162 \\
\hline $\begin{array}{l}\text { Number of contacts } \\
\text { per index patient }\end{array}$ & $3(1,6)$ & $0(0,0)$ & $7(4,11)$ & $3(1,6)$ & $3(2,5)$ \\
\hline \multicolumn{6}{|c|}{ Quarantine after contact with positive } \\
\hline Number of days & 639153 & $\mathrm{~N} / \mathrm{A}$ & 31615 & 445468 & 162003 \\
\hline $\begin{array}{l}\text { Number of } \\
\text { infections during } \\
\text { quarantine }\end{array}$ & 9551 & N/A & 333 & 6009 & 3209 \\
\hline $\begin{array}{l}\text { Percentage of } \\
\text { quarantine leading } \\
\text { to infection }\end{array}$ & 14.9 & $\mathrm{~N} / \mathrm{A}$ & 10.5 & 13.5 & 19.8 \\
\hline \multicolumn{6}{|l|}{ Quarantine after travelling } \\
\hline Number of days & 273189 & $\mathrm{~N} / \mathrm{A}$ & 85490 & 121202 & 66429 \\
\hline
\end{tabular}

Continued 
Table 2 Continued

\begin{tabular}{llllll}
\hline & Overall & $\begin{array}{l}\text { From 25 February 2020 } \\
\text { to 27 April 2020 }\end{array}$ & $\begin{array}{l}\text { From 27 April 2020 to } \\
\text { 24 September 2020 }\end{array}$ & $\begin{array}{l}\text { From 24 September 2020 } \\
\text { to 14 February 2021 }\end{array}$ & $\begin{array}{l}\text { From 14 February 2021 } \\
\text { to 2 June 2021 }\end{array}$ \\
\hline $\begin{array}{l}\text { Number of } \\
\text { infections during } \\
\text { quarantine }\end{array}$ & 96 & N/A & 29 & 42 & 25 \\
$\begin{array}{l}\text { Percentage of } \\
\text { quarantine leading } \\
\text { to infection }\end{array}$ & 0.35 & N/A & 0.34 & 0.35 & 0.38 \\
\hline
\end{tabular}

Periods are presented by grouping together the first wave of cases, the period between the first and the second wave, the second wave and the following period of sustained epidemic activity, and finally the more recent period following the start of the vaccination campaign.

ARGOS, Actionable Register of Geneva Outpatients and inpatients with SARS-CoV-2.

completely replaced SARS-CoV-2 wild type . At the same time, federal and local policies evolved and testing among symptomatic children over 5 years old was newly encouraged. Concurrently with these changes, the incidence of the 0-19 years age population almost doubled to reach those of the older age categories. ${ }^{19-21}$ The positivity rate during this period was $15.9 \%$.

As of 8 February 2021, quarantine measures for close contacts were lifted after 7 days if the person tested negative for SARS-CoV-2. Concurrently, the percentage of close contacts tested positive increased (see table 2). Considering vaccination program, the first dose of vaccine in Geneva was given to an elderly patient on 28 December 2020. At first, only residents over 74 years old and patients with risk factors received vaccination. The decline of the incidence for people of the corresponding age category compared with the others can be observed since February 2021 in figure 2.

\section{March to 1 June 2021 (fourth phase)}

On 1 March 2021, access to vaccination continued to broaden. Residents over 65 years were allowed to be vaccinated since 17 March 2021, followed by the 45-65 years old residents starting on 12 April 2021. By 19 May 2021, all Geneva residents over 15 years old were eligible

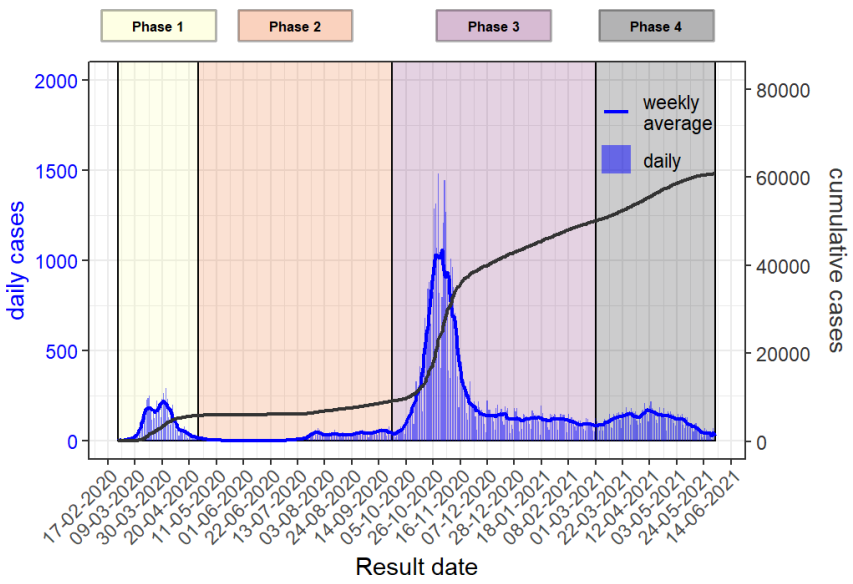

Figure 1 Epidemic curve of the cases of COVID-19 in Geneva state, 26 February 2020-1 June 2021. Vertical bars represent the daily cases (based on the date of the test result), solid blue line represents the weekly moving average and the solid black line the cumulative cases. to get vaccinated. The incidence COVID-19 among the 65-79 years old population started to decline by end of March (figure 2), followed by a rapid decline of the incidence overall by mid-May. The amount of screening tests increased, as $21 \%$ of the positive tests were performed during screening campaigns. The positivity rate decreased to $5.2 \%$ during this period.

\section{DISCUSSION}

COVID-19 represents a major challenge to each country's healthcare system. Collaboration between healthcare providers and public health authorities is particularly important in order to improve both our understanding of the disease and our response. ${ }^{22-24}$ The publication of the ARGOS cohort underscores our willingness to share data for research purposes. Indeed, data from this registry has already been used to investigate symptoms and long COVID- $19,{ }^{25}$ infection fatality rate, ${ }^{9}$ reinfection rates, ${ }^{26}$ as well as viral load kinetics ${ }^{27}$ and healthcare-related COVID-19 infections ${ }^{28}$. Several projects using these data to develop more accurate mathematical models estimating transmission chains are also ongoing.

Furthermore, analysis from the ARGOS database illustrates the impact of various testing policies on the

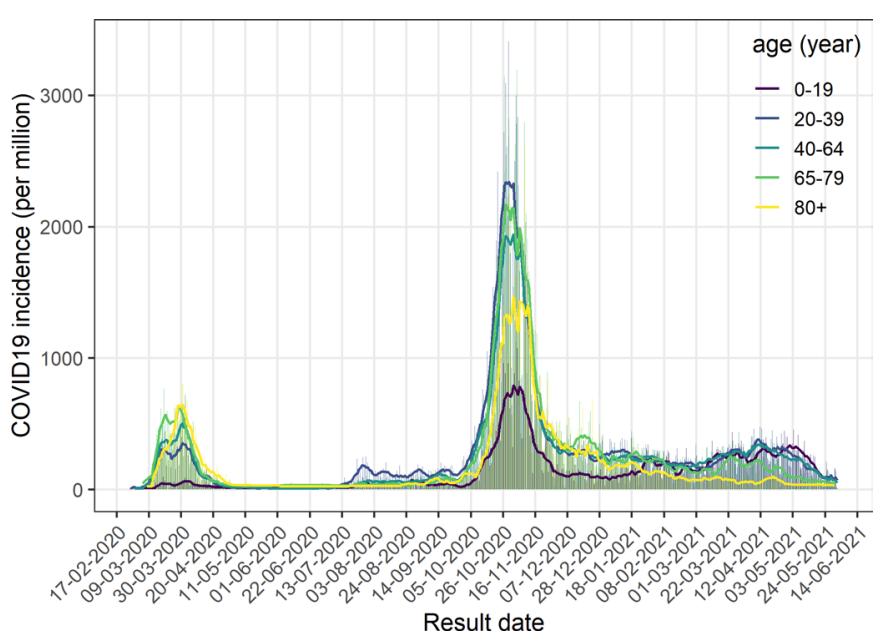

Figure 2 Incidence per age category, Geneva, 26 February 2020-1 June 2021. Vertical bars represent the daily incidence, solid line represent the weekly moving average. 
proportion of risk factors or age groups identified among confirmed cases. The partition of data analysis and interpretation according to policy period confirms the variations within each group depending on the period of interest and could thus guide public health decisions.

\section{Strength and limitations}

The state of Geneva accounts for half a million residents and the local Directorate of Health ordered the recording of all COVID-19 positive cases since the beginning of the epidemic, according to recommendations from the FOPH. Due to this policy, the database's main strength consists of its large number of cases, representative of all diagnosed cases on a regional level primarily serving operational needs and not scientific purposes, with one main objective: assessing all cases. This cohort is also multicentric as it includes all recorded tests performed in Geneva's hospitals (both public and private), private practices and medical centres. The fact that a very large proportion of all cases are assessed reduces the risk of biased data. Also, as data is recorded on the day of the call to the patient, recall bias is very low. Finally, the ARGOS database is characterised by a high number of follow-ups.

Despite these strengths, ARGOS has been influenced by the testing policy and the results must be seen in light of these influences. Seroprevalence study results confirm the under-representation of certain groups and the undertesting of the overall population. ${ }^{8}$ First, individuals without risk factors for COVID-19 and those younger than 65 years old are under-represented in the database during the testing restriction period. The shapes of the graphics in figures 1 and 2 confirm the impact of this policy as there is a sudden decrease in number of cases after 20 March 2020, when restriction started. Other factors could have amplified this phenomenon such as less symptomatic forms of disease in younger people and children. Reasons to get tested have also evolved over the first months of the epidemic. For example, anosmia or ageusia became a testing criteria only in late April 2020. Patients who presented with these isolated symptoms within the first 2 months of the epidemic could thus have been undertested. In addition, as from April 2021, negative results for tests performed on asymptomatic persons in order only to travel or to access events or specific sites were not subject to mandatory reporting and are therefore not part of the database. ${ }^{8}$

ARGOS has several other limitations. First, measurement error due to lack of detail of some variables can be observed, since efficiency is prioritised over detailoriented data collection. For instance, individuals' level of education is not recorded. Furthermore, fear of sanction could lead to underreporting of compliance to isolation and quarantine measures. However, compliance is assessed by asking the patient whether he or she is able to comply to measures and by offering solutions (eg, online grocery shopping or dog-walking by a third-party) if not. Second, misclassification also certainly occurs as symptoms and risk factors are self-reported. Moreover, recording of information in ARGOS is performed by a large and evolving team of professionals, including healthcare workers with various backgrounds, medical students, police recruits or contact tracers with no particular medical and health knowledge. Due to the crisis situation, training contents delivered to the GDH team has continuously evolved, leading to a certain level of heterogeneity of phone interviews and a greater risk for misclassification of medical information. Third, the patient information gathered is tailored to operational needs and growing scientific knowledge. For example, anosmia and ageusia were initially classified as general ENT symptoms, and were later detailed separately as they were recognised as frequent and specific manifestations of COVID-19. ${ }^{29}$ Finally, during some periods of the pandemic, the GDH team was overworked and could not call nor verify selfreported information for all positive cases. This resulted in missing and incomplete data.

In conclusion, ARGOS is a large, real-world registry of individuals tested for SARS-CoV-2 ${ }^{1}$. Unlike many other registries, it involves every tested individual and is not limited to hospitalised patients, thus providing a precious resource to assess the impact of public health policies and overall disease burden of COVID-19.

\section{COLLABORATION}

The publication of the ARGOS cohort underscores our willingness to share data for research purposes and for optimising public health measures. Deidentified ARGOS data are available on reasonable request, including a research protocol, using the online form (https://edc. hcuge.ch/surveys/?s=TLT9EHE93C).

\section{Author affiliations}

${ }^{1}$ Division of General Surgeon, Republic and Canton of Geneva Directorate of Health, Geneva, Switzerland

${ }^{2}$ Division of Primary Care Medicine, Department of Community Medicine and Primary Care and Emergency Medicine, Geneva University Hospitals, Geneva, Switzerland

${ }^{3}$ Faculty of Medicine, University of Geneva, Geneva, Switzerland

${ }^{4}$ Department of Internal Medicine, Geneva University Hospitals, Geneva, Switzerland ${ }^{5}$ Infection Control Program, Geneva University Hospitals, Geneva, Switzerland ${ }^{6}$ Department of Acute Medicine, Geneva University Hospitals, Geneva, Switzerland ${ }^{7}$ Department of Informatics, University of Geneva, Geneva, Switzerland

${ }^{8}$ Quality of Care Service, Geneva University Hospitals, Geneva, Switzerland

Acknowledgements We thank all members of the COVID-19 team at the General Directorate of Health, as well as all healthcare providers, testing centers and laboratories involved in the management of patients with COVID-19. We also wish to thank all patients and their contacts who are included in the ARGOS database.

Contributors Each author contributed to this article, based on the criteria of the International Committee for Medical Journal Editors. CG conceptualised, designed the article format, interpreted the data and conducted the literature review. DM conducted the data analysis and participated in its formulation and its interpretation in the text. CG and DM updated the article content and data according to the reviewers's comments. FK conceptualised and designed the article format, interpreted the data and conducted the literature review. DL participated to the article design and reviewed it. DSC, as guarantor, designed the study's analytic strategy, reviewed the article and revisited it critically. SR, J-LF, PC, MG, ED, MN, OB, DJ, IG, JS and AT helped acquisition of data and reviewed the article's content critically. All authors gave final approval of the version to be published and agreed to be accountable for all aspects of the work. 
Funding ARGOS is supported by Geneva State public funds and the research project SELFISH financed by the Swiss National Science Foundation LIVES, grant number 51NF40-160590.

Competing interests None declared.

Patient and public involvement Patients and/or the public were not involved in the design, or conduct, or reporting, or dissemination plans of this research.

Patient consent for publication Not applicable.

Ethics approval Research received the agreement of the Cantonal Ethic Committee of Geneva (CCER protocol 2020-01273).

Provenance and peer review Not commissioned; externally peer reviewed.

Data availability statement Data are available upon reasonable request. Deindentified ARGOS data can be available upon reasonable request, including a research protocol.

Open access This is an open access article distributed in accordance with the Creative Commons Attribution Non Commercial (CC BY-NC 4.0) license, which permits others to distribute, remix, adapt, build upon this work non-commercially, and license their derivative works on different terms, provided the original work is properly cited, appropriate credit is given, any changes made indicated, and the use is non-commercial. See: http://creativecommons.org/licenses/by-nc/4.0/.

\section{ORCID iDs}

Flora Koegler http://orcid.org/0000-0001-5283-2413

Mayssam Nehme http://orcid.org/0000-0001-9189-6495

Delphine S Courvoisier http://orcid.org/0000-0002-1956-2607

\section{REFERENCES}

1 Cucinotta D, Vanelli M. WHO Declares COVID-19 a pandemic. Acta Biomed 2020;91:157-60.

2 Coronaviridae Study Group of the International Committee on Taxonomy of Viruses. The species severe acute respiratory syndrome-related coronavirus: classifying $2019-n C o V$ and naming it SARS-CoV-2. Nat Microbiol 2020;5:536-44.

3 Dong E, Du H, Gardner L. An interactive web-based dashboard to track COVID-19 in real time. Lancet Infect Dis 2020;20:533-4.

4 Roser M, Ritchie H, Ortiz-Ospina E. Coronavirus Pandemic (COVID-19). Our World Data [electronic article], 2020. Available: https://ourworldindata.org/coronavirus [Accessed 02 Aug 2020].

5 OFSP. Rapport quotidien sur la situation épidémiologique en Suisse et dans la Principauté de Liechtenstein. 2020;(Rapport quotidien sur la situation épidémiologique en - BAG. Available: https://www.bag. admin.ch , bag , covid-19-lagebericht.pdf.download.pdf

6 DSES. COVID-19 - données complètes depuis le début de la pandémie. GECH - Répub. Cant. Genève, 2020. Available: https:// www.ge.ch/document/covid-19-donnees-completes-debutpandemie [Accessed 02 Aug 2020].

7 OFSP. Nouveau coronavirus COVID-19: premier Cas confirmé en Suisse, 2020. Available: https://www.bag.admin.ch/bag/fr/home/dasbag/aktuell/medienmitteilungen.msg-id-78233.html [Accessed 02 Aug 2020].

8 Stringhini S, Wisniak A, Piumatti G. Repeated seroprevalence of anti-SARS-CoV-2 IgG antibodies in a population-based sample from Geneva, Switzerland. medRxiv:2020;2020.05.02.20088898.

9 Perez-Saez J, Lauer SA, Kaiser L, et al. Serology-informed estimates of SARS-CoV-2 infection fatality risk in Geneva, Switzerland. Lancet Infect Dis 2021;21:e69-70.
10 Harris PA, Taylor R, Thielke R, et al. Research electronic data capture (REDCap)--a metadata-driven methodology and workflow process for providing translational research informatics support. J Biomed Inform 2009;42:377-81.

11 Harris PA, Taylor R, Minor BL, et al. The REDCap Consortium: building an international community of software platform partners. $J$ Biomed Inform 2019;95:103208.

12 Marty FM, Chen K, Verrill KA. How to obtain a nasopharyngeal swab specimen. N Engl J Med 2020;382:e76.

13 Guan W-J, Ni Z-Y, Hu Y, et al. Clinical characteristics of coronavirus disease 2019 in China. N Engl J Med 2020;382:1708-20.

14 Vetter P, Vu DL, L'Huillier AG, et al. Clinical features of covid-19. BMJ 2020;369:m1470.

15 Huang C, Wang Y, Li X, et al. Clinical features of patients infected with 2019 novel coronavirus in Wuhan, China. The Lancet 2020;395:497-506.

16 Giacomelli A, Pezzati L, Conti F, et al. Self-Reported olfactory and taste disorders in patients with severe acute respiratory coronavirus 2 infection: a cross-sectional study. Clinical Infectious Diseases 2020;71:889-90.

17 Greenhalgh T, Koh GCH, Car J. Covid-19: a remote assessment in primary care. BMJ 2020;368:m1182.

18 ECDC. Rapid risk assessment: coronavirus disease 2019 (COVID-19) pandemic: increased transmission in the EU/EEA and the UK eighth update. Eur. cent. Dis. Prev. control, 2020. Available: https:// www.ecdc.europa.eu/en/publications-data/rapid-risk-assessmentcoronavirus-disease-2019-covid-19-pandemic-eighth-update [Accessed 02 Aug 2020].

19 Davies NG, Abbott S, Barnard RC, et al. Estimated transmissibility and impact of SARS-CoV-2 lineage B.1.1.7 in England. Science 2021;372:eabg3055.

20 Volz E, Mishra S, Chand M, et al. Assessing transmissibility of SARSCoV-2 lineage B.1.1.7 in England. Nature 2021;593:266-9.

21 Forbes H, Morton CE, Bacon S, et al. Association between living with children and outcomes from covid-19: OpenSAFELY cohort study of 12 million adults in England. BMJ 2021;372:n628.

22 Islam N, Sharp SJ, Chowell G, et al. Physical distancing interventions and incidence of coronavirus disease 2019: natural experiment in 149 countries. BMJ 2020;370:m2743.

23 Koo JR, Cook AR, Park M, et al. Interventions to mitigate early spread of SARS-CoV-2 in Singapore: a modelling study. Lancet Infect Dis 2020;20:678-88.

24 Baker MG, Wilson N, Anglemyer A. Successful elimination of Covid-19 transmission in New Zealand. N Engl J Med Overseas Ed 2020;383:e56.

25 Nehme M, Braillard O, Alcoba G, et al. COVID-19 symptoms: longitudinal evolution and persistence in outpatient settings. Ann Intern Med 2021;174:723-5.

26 Leidi A, Koegler F, Dumont R, et al. Risk of reinfection after seroconversion to SARS-CoV-2: a population-based propensityscore matched cohort study. Clin Infect Dis 2021:ciab495.

27 Bellon M, Baggio S, Jacquerioz Bausch F, et al. Severe acute respiratory syndrome coronavirus 2 (SARS-CoV-2) viral load kinetics in symptomatic children, adolescents, and adults. Clin Infect Dis 2021;73:e1384-6.

28 Mongin D, Catho G, Iten A, et al. Incidence of healthcare-associated coronavirus disease 2019 (COVID-19) in the state of Geneva. Infect Control Hosp Epidemiol 2021:1-3.

29 Lechien JR, Chiesa-Estomba CM, De Siati DR, et al. Olfactory and gustatory dysfunctions as a clinical presentation of mildto-moderate forms of the coronavirus disease (COVID-19): a multicenter European study. Eur Arch Otorhinolaryngol 2020;277:2251-61. 